\title{
The "Super-Destroyer"
}

\author{
Some Facts Concerning the Origin and Development of the Flotilla Leader
}

\section{By Hector C. Bywater}

\begin{abstract}
THE flotilla leader, which is a super1 destroyer, is a new type of vessel developed during the recent war. These vessels are used to lead flotillas of destroyers into action. Being larger than destroyers they carry the essential facilities for a flotilla commander. They are better equipped for signaling and rangebetter equipped for signaling and range-
finding, carry a heavier battery, and a finding, carry a heavier battery, and a much more efficient radio equipment than a destroyer. They proved themselves to now generally recognized as being required by modern organization for destroyer operations. Also, these larger vessels were found necessary for screening battle-cruisers, where the ability to
\end{abstract} maintain high speed in a seaway is a prime necessity.

The foregoing admirable summary of the functions of the flotilla leader is contained in the recommendations made by the General Board of the United States Navy for the building program of 1921. Five vessels of this type were included in the Board's program, which, however, has not been accepted by Congress, with the result that, for the next few years the United States Navy will have to do without a type of fighting ship which is possessed and highly prized by the other ship which is possessed and highly prized by the other type revived under a new name. It is the modern type revived under a new name. It is the modern descendant of the "divisional torpedo-boat" and the "torpedo-gunboat" built during the closing decades of the $19 \mathrm{th}$ century, types which, in their turn, had sprung from the sea-going torpedo-boat and eventually became merged in the destroyer. The credit of having invented the flotilla leader must go to Germany, who some forty-five years who some forty-five years
ago ordered the "Zieten," a ago ordered the "Zieten," a fast "torpedo aviso," from the Thames Ironworks of London. Although but 975 tons in displacement and barely 200 feet in length, she had a speed of 16 knots, she had a speed of 16 knots, and carried a powerul and carried a powerful armament of breech-loading guns, with submerged tubes at bow and
stern for ejecting the "fish" stern for ejecting the "fish" torpedo. The success of the "Zieten" led other powers to experiment with vessels of this type, from which there grew a very numerous family. It was only in Germany, however, that the original function of the "Zieten" as a leader of torpedo boats was kept steadily in view, though lack of funds prevented that country in view, though lack of fund

In 1906 tactical maneuvers held in the North Sea convinced the British Admiralty that the system of
using destroyers in large flotillas of twelve to twenty boats necessitated the building of special leaders, or flag boats, from which the commodore in command could control his flotilla just as an admiral handles a squadron or fleet of battleships from his flagship. Since the ordinary destroyer did not offer sufficient bridge room, living accommodations, and other facilities for the commodore and his staff, it was considered necessary to design a vessel of larger dimensions, fitted up as a miniature flagship, and possessing superior qualities of speed and armament. The pioneer vessel of this type was the "Swift," ordered from Cammell-Lairds of Birkenhead, in 1906. She displaced 1,825 tons, was 353 feet in length and $341 / 2$ feet broad, and was equipped with turbine machinery of 30,000 S.H.P. with turbine machinery of 30,000 S.H.P. to produce the then phenomenal speed of 35 knots, which was at least five knots
more than the best British destroyer of more than the best British destroyer of the period could make. The trials of this vessel, which was launched in 1907 , wer-
watched with keen interest, as few engineers believed she would ever make her neers believed she would ever make her
contract speed. But the first runs over

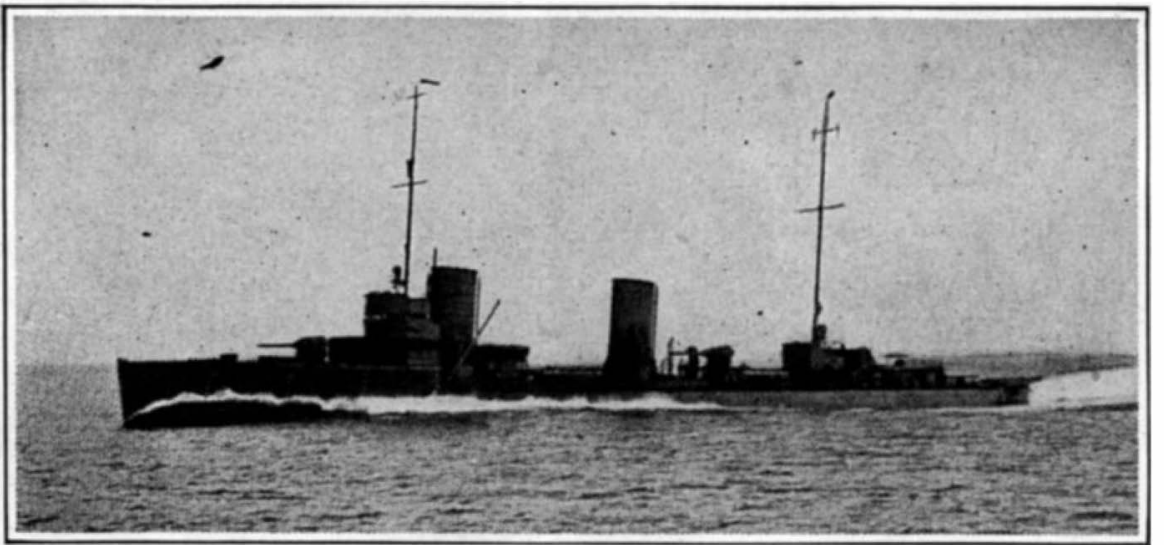

German flotilla leader "V-116," of 2,400 tons, completed 1918 . Speed, 35 knots for 55,000 horse-power. Armament: four 5.9-inch, one 3.4-inch (anti-aircraft); company with the "Broke," she fell upon six German destroyers in the Dover Strait and routed them with heavy loss, will long be remembered. Shortly before that action her original armament of four 4-inch rapidfire guns had been changed to one 6-inch and two 4-inch, so that she was a most formidable opponent for any destroyer. Various structural modifications have now
brought her displacement up to 2,207 tons, but she is still good for 35 knots.

The value of the flotilla leader is evidenced by the fact that during the war period every naval belligerent, with the exception of the United States, built many vessels of this type. Great Britain added no less than vessels of this type. Great Britain added no less than
34 of them to her fleet; Germany laid down flotilla run at full power gave a maximum velocity of 38.3 knots-a world's record which remained unbroken for the success of this innovation encouraged the British Admiralty to embody the liquid fuel system in their further leaders were built until 1913, in which year "She "Marksman" and "Lightfoot" were laid down. The "Swift" performed most valuable service during the
war, and her dashing exploit in April, 1917, when, in \section{hea} her inordinate cost- $£ 280,500 \quad(\$ 1,402,500$ at normal nd torpedo tubes. It was not until a whole series of
eir boats had been sunk or badly mauled by the eavier gunfire of British destroyers that they departed from this rigid principle. All the German prewar boats mounted 3.4-inch 22-pounder guns, which were soon replaced by the 4.1 -inch 38-pounder with a semi38-pounder with a semi-
automatic breech-block, enabling a very high rate of abling a very high rate of
fire to be maintained. Guns fire to be maintained. Guns of this caliber were supplied
to nearly all the boats built during the war, and proved superior in range and smashing power to the British 4inch. But it cannot be said that the German destroyers ever took kindly to artillery duels, and to the end of the war they never used their guns to full advantage. What the big superleaders of the "V-116" class might have done can only be surmised, for none of them was commissioned in time to take an active part in the war. A great mystery has been made in Germany about these twelve boats and the details of them given. in the above list have not previously been published. Five boats were completed in the spring of 1918 and ran their trials in the Baltic. Most of them exceeded the designed speed of 35 knots, but the great weight of armament and the immensely powerful machinery proved too much for the scantlings, and all five had to go into dockyard for extensive alterations, which were still incomplete at the date of the armistice. The four 5.9-inch guns were on high-angle mounts and could $r$ for flat trajectory fire or against aircraft. The projectile weighed 101 pounds bursting charge, which would have proved bursting charge, which would have proved
most effective against such comparatively. most effective against such comparatively-
flimsy targets as destroyers. The torpedo. armament was limited to four tubes, mounted in pairs amidships, but these fired the new 23.6-inch torpedo, which is the most powerful weapon of its kind in existence. Its warhead is charged with pounds of T.N.T.-practically double the quantity of explosive carried in prewar torpedoes-and it can travel a distance of 16,350 yards at a velocity of 28 knots. Since it would be impossible to manipulate torpedoes and tubes of this size by hand, the "V-116" and her sister boats had special motors for loading and training the tubes. They were also fitted with the latest appliances for controlling (Continued on page 482) 
H.

THE SHOE THAT HOLDS ITS SHAPE

\$7.00 \$8.00 \$9.00 \& \$10.00 SHOES

FOR MEN AND WOMEN

YOU GAN SAVE MONEY BY WEARING

W. L. DOUGLAS SHOES

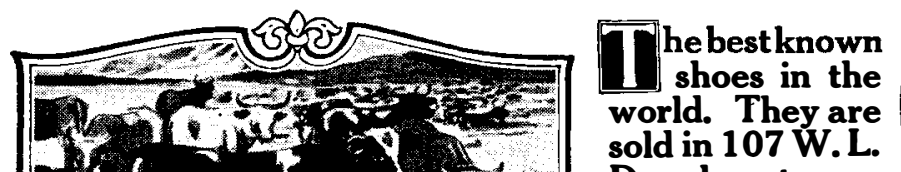
world. They are
sold in $107 \mathrm{~W}$. L.

Douglas stores

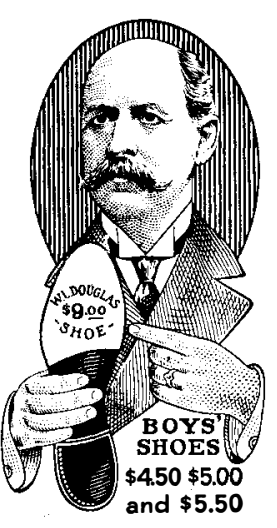

direct from the factory to you at only one profit, which guarantees to you the best shoes that can be produced, at the lowest possible cost. W. L. Douglas name and the retail price are stamped on the bottom of all shoes before they leave the factory, which is your protection against unreasonable profits.

W. L. Douglas $\$ 9.00$ and $\$ 10.00$ shoes are absolutely the best shoe values for the money in this country. They are made of the best and finest leathers that money can buy. They combine quality, style, workmanship and wearing qualities equa to other makes selling at higher prices. They are the leaders in the fashion centers Douglas personal guarantee that the shoes are always worth the price paid for them The prices are the same everywhere; they cost no more in San Francisco than they do in New York.

W. L. Douglas shoes are made by the highest paid, skilled shoemakers, under the direction and supervision of experienced men, all working with an honest the price that money can buy.

W. L. Douglas shoes are for sale by over 9000 shoe dealer you, take no other make. Order direct from factory. Send
for booklet telling how toorder shoes by mail,postagefree. President
Pouglas Shoe Co,
3rockark Street,
Bron, Mass.

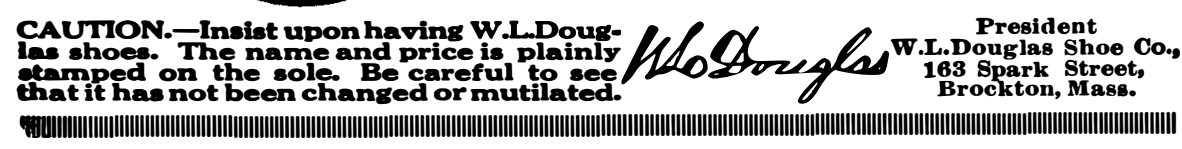

Whatever Your Question; -be it the pronunciation of Bolsheviki, the spelling of a puzzling word, the location of
Murman Coast-the meaning of blighty, etc., this Supreme Authority WEBSTER'S NEW INTERNATIONAL DICTIONARY

contains an accurate, final answer. 400,000 Words. 2700 Poyes. 6000 lllustrations.
Regulor and India-Poper Editions. G. \& C. MERRRIAM CO. Springfield. Mass.
Write for specimen pages. prices. etc. and FREE Pocket Mops per Sc. Am.

\section{R E L A T I V I T Y}

\section{The Special and the General Theory}

By Professor Albert Einstein, Ph.D. LL.D.

Translated by Professor Robert W. Lawson, M.Sc.

$T$

HE authorized English translation of Einstein's own book explain-

ing his theories to the general public is now available. Dr. Einstein
ing has scored a conspicuous success in this volume, steering a skillful course explanation. Also, he makes clearer than has yet been made just wherein lies the dividing line between his special theory and his general theory, and just where the two join. In literary style as well as in clarity of exposition this book bids fair to take rank as a classic; and in any event, it is by far the most satisfactory treatment of the subject to be had at the presen date in English.

Price $\$ 2.50$, by Mail $\$ 2.58$

For Sale by

SCIENTIFIC AMERICAN PUBLISHING CO. 233 Broadway stalled and these loaded directly upon'Japanese boats of the Akikaze class, dump cars which were hauled away by building under the estimates for the curelectric locomotives, trains being made up rent year. They will displace 1,900 tons of five or six cars. Except where water and have a speed of 38 knots. Four, or was encountered in large volume, some possibly five, 5.5-inch 82-pounder rapidof the tunnel crews made as high as 12 fire guns will be mounted on the centerline, feet a day, and the work of drilling and and all six torpedo tubes can be trained mucking went on simultaneously. A
heading, approximately 8 feet high and either beam. A feature of these boats
is their large fuel capacity, which is exthe full width of the tunnel, was carried is their large fuel capacity, which is exapproximately 7 feet ahead of the bench. pected to give them a cruising radius As soon as the shooting from a preceding It will be seen that the modern flotilla shift had been completed, the steam leader approximates to the light cruiser shovel men immediately commenced to in dimensions and armament. If the re load out the muck which had been blown back from the face. The machine men and chuck tenders at the same time start work on the top of the muck and shovel back the material which still remains on top of the bench. By carrying a short bench, it is possible to clear the same with a minimum amount of hand mucking, thus enabling the drilling in the face to proceed at the same time that the steam shovel is mucking out the heading. This makes it possible for the tunnel work to proceed

At one of the

At one of the tunnels a different cre the much and mucking gangs, and worked separately. A car was specially built upon which was jack on each end, with 4 cross bars mounted on the same, the drills being mounted on the cross bars. By this method the entire face of the tunnel was method the entire face of the tunnel was started to work, and each crew worked in started to work, and each crew worked in
shifts. By this method a maximum speed of 90 feet in one week was obtained. Considerable rivalry existed between the various crews, and as the progress malle by each crew was posted, the men working in the different tunnels endeavored to outdo each other with the result that excellent progress was made in all departments.

The three penstock lines are of riveted steel pipe, 7 feet in diameter at the lower end and 8 feet in diameter at the upper end, at which point they are conforebay 17 feet in diameter at the top 80 feet in height and 40 feet in diameter at the top of the tunnel, has been excavated in solid rock a short distance from the outlet of the tunnel, where the penstock joins the same. The purpose of the forebay, from which a spillway leads to the river, is to take care of surges due to sudden increases and decreases in load at the plant.

From the power house a 110,000 -volt transmission line about 75 miles in length carries the current to a point near Tulare carries the current to a point near Tulare tributing system for use where needed. tributing system for use where needed.
Since the hydroelectric lines of all California companies have been connected up for emergency use, it is possible to send of the State for use.
onser

\section{The "Super-Destroyer"}

\section{(Continued from page 472)}

the guns, including director aiming and firing mechanism. It is, however, doubtful whether all this cumbersome and intricate gear was suitable for vessels which were simply enlarged destroyers, and therefore exposed to the sort of rough and tumble fighting in which headlong dash counts for more than science. Moreover, 5.9-inch gun, with its 101-pound projectile, is much too heavy to be conveniently manhandled on the slippery decks of a boat which is moving all ways at once. In theory, the German "V-116" leaders ought to have made short work of any destroyers they were likely to meet in the North Sea ; in practice they would probably have been beaten by the smaller British boats armed with the handy 4-inch and 4.7-inch gun. tilla leader is represented by the five new in dimensions and armament. If the recent rate of progress is to be maintained, "boat" will soon become a misnomer, and of thirty years ago, though on a much arger scale. In the destroyer and flotilla leader, as in every other type of fighting craft, each new demand for increased armament, speed and sea endurance involves a corresponding increase in size, and there is practically no limit except in the paying power of the nations conerned. But in every class of fighting ship there comes a stage of development which fulfils all reasonable requirements, and beyond which it is unnecessary to go. In the case of the flotilla leader this stage ppears to have been reached in the maller designs set forth in the table shown. War experience has demonstrated the all-round tactical efficiency of such vessels as the British Scott class, which, on the relatively modest displacement or 1,740 tons, combine in a high degree the essential qualities of a destroyer flagship. It is of interest to learn that a tentative provided for a vessel of 1,800 to year tons, of 37 knots speed, armed with four 5-inch rapid-fire guns and eight torpedo tubes.

Golf Without a Caddy

(Continued from page 473)

in fact works out much more wisely than anticipated; when a few ounces can save upward of 25 tons as above, the ounces are certainly working at some high efficiency Think of the perspiration and utter exhaustion that would overtake one were he compelled to go out and raise 25 tons to the height of 1 foot by hand twice a day. How much of either energy or inclination for golf would a man have after such an exertion, or by taking the stairs climb about 30 stories in one of our tall buildings twice a day? And this is exactly what caddiless golf has been doing to us without our ever suspecting it. to, the simple act of resting the bag down on the ground causes it to develop legs which keep it upright and very stable, and with my eye on the ball and without looking around, I am able simply to reach back, grasping the bag, and the act of lifting it from the ground causes the legs lifting it from the ground causes the legs ordinary "Sunday" bag and is little or no heavier.

Another point that I have found important is the following: We all know that "keep your eye on the ball" is even more necessary after the shot is made than while making it, if you have no caddie. It is then the player's job to watch the ball-certainly no caddie is watching it for him Again, one often loses the lie of the ball in the rough while stooping down to get his sticks, thus causing exasperating delays. I have found that it is certainly of surprising convenience to have the sticks right at hand, standing to simply reach back, grasping the bag while watching your ball, and be off on the ext stroke toward the drop long before holding your position on the course and I find often aids a whole foursome to hold its position in play. The unerring location of, and getting right off on the ball is ertainly an aid, both directly and indirectly, that can hardly be overestimated. to us without our ever suspecting it.
With the little device I have referred the ball lights. This is of great aid in 